\title{
Syndromes that Link the Endocrine System and Genitourinary Tract
}

\author{
Yasemin ÖZLÜK, Işın KILIÇASLAN \\ Department of Pathology, Istanbul Faculty of Medicine, Istanbul University, ISTANBUL, TURKEY
}

\begin{abstract}
The endocrine system and genitourinary tract unite in various syndromes. Genitourinary malignancies may cause paraneoplastic endocrine syndromes by secreting hormonal substances. These entities include Cushing's syndrome, hypercalcemia, hyperglycemia, polycythemia, hypertension, and inappropriate ADH or HCG production. The most important syndromic scenarios that links these two systems are hereditary renal cancer syndromes with specific genotype/phenotype correlation. There are also some very rare entities in which endocrine and genitourinary systems are involved such as Carney complex, congenital adrenal hyperplasia and Beckwith-Wiedemann syndrome. We will review all the syndromes regarding manifestations present in endocrine and genitourinary organs.
\end{abstract}

Key Words: Urogenital system, Endocrine system, SDH, TMEM127, VHL

\section{INTRODUCTION}

In this article, we focus on the relationship between the endocrine system and genitourinary tract. This review includes two main topics. First, the paraneoplastic "endocrine" syndromes that occur in the presence of a genitourinary malignancy, and second, hereditary syndromes including both the endocrine system and genitourinary tract. These are discussed based on findings related to both systems.

\section{PARANEOPLASTIC ENDOCRINE SYNDROMES RELATED TO THE GENITOURINARY TRACT}

Paraneoplastic syndromes occur in $15-20 \%$ of all cancer patients. Paraneoplastic syndromes include endocrinologic, dermatologic, hematologic, neurologic, and osteoarticular manifestations (1). Paraneoplastic endocrine syndrome (PNES) is characterized by complex signs and symptoms related to ectopic production of a hormone or hormonal substance by tumor cells that do not normally produce these molecules. It is important to recognize these syndromes because they may lead to early recognition of cancer, the hormonal substances produced may be used as tumor markers, and they are a major cause of morbidity and mortality. PNES is usually managed by treating the underlying disease.

PNES caused by genitourinary cancers are rare, but have been reported. Renal cell carcinoma (RCC) is the most frequent urologic malignancy that causes paraneoplastic

(Turk Patoloji Derg 2015, 31(Suppl):155-171)

Received : 11.06.2015 Accepted : 12.06.2015 syndrome, followed by prostate cancer (1). PNES related to genitourinary malignancies are summarized in Table I. Most PNES are associated with neuroendocrine tumors, whereas humoral hypercalcemia of malignancy is primarily linked with squamous cell carcinoma (2). Paraneoplastic syndromes are uncommon among bladder and testicular cancers.

\section{A. Paraneoplastic Hypercortisolism (Cushing's Syndrome)}

Inappropriate synthesis of corticotropin-releasing hormone $(\mathrm{CRH})$ or adrenocorticotropic hormone (ACTH) determines overproduction of gluco- and/or mineralocorticoids from adrenal cortex. It may occur either by secretion of $\mathrm{CRH}$ or ACTH. The most common cause is the ectopic production of pro-opiomelanocortin (POMC), which is the precursor polypeptide of ACTH. Ectopic ACTH directly stimulates the adrenal cortex, which causes cortical hyperplasia and hypercortisolism. Clinically, patients with paraneoplastic hypercortisolism present with symptoms of Cushing's syndrome (CS), such as central obesity, round face, excess sweating, red stria, muscle weakness, osteoporosis, hyperpigmentation, hypertension, insulin resistance, and psychologic disturbances. Muscle weakness caused by marked hypokalemia may be the first and dominant clinical symptom (3).

Among genitourinary malignancies, prostate, bladder, and renal cell carcinoma may cause CS (3-8). Prostate carcinomas are of interest in which normal levels of

Correspondence: Yasemin ÖZLÜK

İstanbul Üniversitesi, İstanbul Tip Fakültesi, Patoloji Anabilim Dalı,

İSTANBUL, TURKEY

E-mail: yasozluk@gmail.com Phone: +90 2124142398 
Table I: Paraneoplastic endocrine syndromes (PNES) related to genitourinary malignancies

\begin{tabular}{|l|c|c|c|c|}
\hline PNES & Renal cell cancer & Prostate cancer & Bladder cancer & Testicular cancer \\
\hline Hypercorticolism (Cushing's syndrome) & $\sqrt{ }$ & $\sqrt{ }$ & $\sqrt{ }$ & \\
\hline Hypercalcemia & $\sqrt{ }$ & $\sqrt{ }$ & \\
\hline Hypertension & $\sqrt{ }$ & & & \\
\hline Alterations in glucose metabolism & $\sqrt{ }$ & & & \\
\hline Polycythemia & $\sqrt{ }$ & & & \\
\hline Inappropriate HCG secretion & $\sqrt{ }$ & $\sqrt{ }$ & \\
\hline Inappropriate ADH secretion & & $\sqrt{ }$ & & \\
\hline
\end{tabular}

PNES: Paraneoplastic endocrine syndromes, HCG: Human chorionic gonadotropin, ADH: Antidiuretic hormone.

testosterone are detected despite medical or surgically castration (9). Although cortisol levels are elevated both in CS due to paraneoplastic hypercortisolism and pituitary gland tumor, paraneoplastic hypercortisolism shows very high ACTH levels and does not respond to dexamethasone suppression test (2).

\section{B. Paraneoplastic Hypercalcemia}

Hypercalcemia of malignancy (HHM) is the most common PNES and seen in $30 \%$ of all patients with hypercalcemia. HHM is related to the production of parathyroid hormonerelated peptide (PTHrP). PTHrP synthesis has been demonstrated in $20 \%$ of patients with cancer regarding breast, lung, and genitourinary tract (10-12). Hypercalcemia may be seen due to ectopic hormone production or localized osteolytic paracrine effect of metastatic tumor to bone or hyperparathyroidism, which may be present in patients with cancer. Ectopic hormone production (mostly PTHrP) with or without bone metastases is defined as PNES, but not hypercalcemia itself. HHM is the most common form of PNES among RCCs $(13-20 \%)(13,14)$ and squamous cell carcinomas of the bladder (15). RCC is also the most common tumor that causes hypercalcemia both in paraneoplastic and nonparaneoplastic mechanisms. Some $75 \%$ of RCCs that cause hypercalcemia are high stage and $50 \%$ have metastasize to bone, although the presence and degree of hypercalcemia have been shown not to be associated with grade or survival (16). Prostate cancer that causes hypercalcemia is extremely rare and is mostly related to disseminated bone metastasis (1). Although rare, penile squamous cell carcinoma may also culminate in hypercalcemia (17).

PTHrP has significant control over proliferation, differentiation, and death of many cell types. It binds to the PTH receptor and increases levels of serum $\mathrm{Ca}^{2+}$ with cAMP-mediated actions. The increase in serum $\mathrm{Ca}^{2+}$ is mediated by an increase in osteoclastic activity, reduced renal clearance of $\mathrm{Ca}$, and decreased renal phosphorus reabsorption. The clinical findings of HHM are seen in various forms. Patients may present with nonspecific symptoms such as asthenia, headache, lack of appetite, vomiting, constipation, and polyuria-polydipsia. A more severe form of HHM with an acute confused or lethargic state or even coma may also be seen especially when $\mathrm{Ca}^{2+}$ levels are $>12 \mathrm{mg} / \mathrm{dl}$. Shock and death occur if $\mathrm{Ca}^{2+}$ levels exceed $18 \mathrm{mg} / \mathrm{dl}$ (2). The measurement of PTHrP can also be helpful in the differential diagnosis.

Differential diagnosis include excessive vitamin D, sarcoidosis and bone metastasis in a patient with hypercalcemia, low levels of phosphorus and chloride accompanied by low PTH levels. Although PTHrP causes hypercalcemia, $\mathrm{Ca}^{2+}$ levels may be normal or even low in prostate carcinoma with neuroendocrine features and PTHrP secretion. This phenomenon is called 'bone hunger syndrome', which is metabolic derangement of metastatic prostate carcinoma. In this syndrome, $\mathrm{Ca}^{2+}$ is entrapped in bone related to excessive osteoblastic activity. This process results in hyperparathyroidism and increased osteoclastic activity in bones apart from at metastatic sites. Cleavage and inactivation of PTHrP by high levels of PSA are also involved in the development of this syndrome (18). Hypercalcemia is often the leading cause of death in patients with PTHrP producing tumors (1).

\section{Paraneoplastic Hypertension}

Hypertension related to RCC was first discovered in a patient whose hypertension was cured after nephrectomy (19). The incidence of hypertension in patients with RCC is reported as $14-35 \%(20)$. RCCs that cause hypertension typically show low-grade clear cell histology. The mechanisms of hypertension in RCC include renin secretion, ureteral obstruction, arteriovenous fistulae, renal artery stenosis, polycythemia, hypercalcemia, and cerebral metastasis (21). Renin is normally secreted by the juxtaglomerular 
apparatus of the nephron and its overexpression results in hypertension. Renin secretion is generally seen in juxtaglomerular tumors but RCCs may rarely show renin secretion. Hypokalemia and hyperaldosteronism are accompanied features of juxtaglomerular tumors but not RCCs with renin production $(19,21)$. There is no clear relationship between hypertension and prognosis among patients with RCC (22). Any etiologic factor that causes ischemia in the kidney increases renin secretion, which is the mechanism in ureteral obstruction, arteriovenous fistulae, and renal artery stenosis. There is no correlation with hypertension and renin level (1). Hypertension is reversible through surgical removal of the renal tumor in most cases $(2,19,23)$.

\section{Paraneoplastic Alterations in Glucose Metabolism}

Abnormalities in glucose metabolism such as hypo- and hyperglycemia occur in RCCs. Insulin and glucagon were shown to be present in RCC tumor extracts (24). Rare cases of RCC leading to diabetes have been published (25, 26). The underlying mechanisms for this syndrome are unknown and no association with metastasis and previous history of diabetes also has been shown. It has been suggested that hormones secreted by RCCs antagonize the effect of insulin or promote glucogenesis and this could cause hyperglycemia (1).

\section{E. Paraneoplastic Polycythemia (Inappropriate Erythropoietin (EPO) Secretion)}

Polycythemia in RCCs accounts for 1-8\% of cases (27). It is believed to be associated with inappropriate secretion of EPO. Although EPO production is documented in $66 \%$ of RCCs, erythrocytosis is only seen in $8 \%$ (27). The other renal tumor that also shows increased EPO secretion is nephroblastoma $(28,29)$. EPO expression in tumor cells has been demonstrated in protein and mRNA levels (3032). EPO production is induced through either hypoxia inducible factor (HIF) or von Hippel Lindau (VHL) mutations without HIF activation $(33,34)$. The VHL gene is the most-frequently involved gene in the pathogenesis of RCC both in sporadic and familial forms (35). Clear cell RCC is thought to originate from proximal tubular epithelium. In contrast with tumor cells, normal proximal tubular epithelial cells were not shown to express EPO even in hypoxic conditions (31). This finding suggested that VHL mutations may play a role in tumor cells that transform into EPO-secreting cells. EPO is more likely involved in local tumor progression rather than metastasis (36). There are conflicting results in terms of the effect of EPO and EPOreceptor expression on the prognosis of RCC (37-39).

\section{F. Paraneoplastic Inappropriate Human Chorionic Gonadotropin (HCG) Secretion}

Elevated levels of HCG have been demonstrated in urine and/or serum samples of genitourinary carcinomas including renal, prostate, and bladder (40). Clinical findings for elevated HCG in males are gynecomastia and decreased libido. There is no direct evidence that tumor cells produce HCG.

\section{G. Paraneoplastic Inappropriate Antidiuretic Hormone (ADH) Secretion}

The syndrome of inappropriate ADH (SIADH) is defined as serum hyponatremia, hypo-osmolality and elevated urinary sodium concentrations with normal renal and adrenal homeostasis (41). Although the plasma level of $\mathrm{ADH}$ is increased, it is not crucial for the diagnosis of SIADH (2). SIADH may be seen in various clinical situations: malignancies, pulmonary and neurologic diseases, endocrine disorders, and as a drug adverse effect. Lung small cell carcinomas are the most frequent malignant tumor in which SIADH is seen (1).

Prostate cancer rarely presents with SIADH and most cases are poorly differentiated adenocarcinomas (42). Primary small cell carcinoma of the prostate is very rare and its SIADH association is even rarer $(43,44)$. Besides high levels of $\mathrm{ADH}$, positive immunoreactivity for anti$\mathrm{ADH}$ antibody has been documented (44). Bladder small cell carcinoma showing SIADH is extremely rare $(45,46)$. No other SIADH-related genitourinary malignancies are reported in the literature.

\section{GENITOURINARY AND ENDOCRINE TUMORS AND TUMOR-LIKE LESIONS IN HEREDITARY SYNDROMES}

\section{A. Hereditary Renal Cancer Syndromes with Endocrine Manifestations}

Hereditary renal cancer syndromes are a heterogenous group of diseases that include renal tumors accompanied by involvement of other visceral organs. The endocrine and genitourinary systems are both affected in some of these syndromes. Here we review hereditary renal cancer syndromes in which endocrine pathologies are seen.

A summary of hereditary renal cancer syndromes with related genetic defects, endocrine and genitourinary manifestations are summarized in Table II.

\section{A1. von Hippel-Lindau (VHL) Syndrome}

VHL is an autosomal dominant heritable neoplasia caused by heterozygous germline mutations in VHL tumor suppressor gene located on the short arm of chromosome 
Table II: Hereditary renal cancer syndromes with endocrine manisfestations

\begin{tabular}{|l|c|l|l|}
\hline Hereditary syndrome & Involved gene & \multicolumn{1}{|c|}{ Genitourinary manifestations } & \multicolumn{1}{|c|}{ Endocrine manifestations } \\
\hline $\begin{array}{l}\text { von Hippel-Lindau } \\
\text { syndrome }\end{array}$ & $V H L$ & $\begin{array}{l}\text { Multiple bilateral CCRCC } \\
\text { Multiple bilateral renal cysts } \\
\text { Epididymal cystadenoma }\end{array}$ & $\begin{array}{l}\text { PHEO/PGL } \\
\text { Pancreatic NETs }\end{array}$ \\
\hline Birt-Hogg-Dubé syndrome & $B H D$ & $\begin{array}{l}\text { Oncocytic renal tumors } \\
\text { (oncocytoma, chromophobe RCC, } \\
\text { hybrid oncocytic tumors with clear cells) }\end{array}$ & Medullary thyroid carcinoma \\
\hline $\begin{array}{l}\text { Hereditary leiomyomatosis } \\
\text { RCC }\end{array}$ & $F H$ & RCC & $\begin{array}{l}\text { Adrenal cortical proliferation and } \\
\text { PHEO/PGL }\end{array}$ \\
\hline Familial PGL syndromes & $\begin{array}{l}\text { RDH } \\
(S D H-B, C, D)\end{array}$ & $\begin{array}{l}\text { SDH mutant renal neoplasia } \\
\text { (CCRCC, papillary RCC, } \\
\text { chromophobe RCC, oncocytoma) }\end{array}$ & PHEO/PGL \\
\hline $\begin{array}{l}\text { Hyperparathyroidism-Jaw } \\
\text { syndrome }\end{array}$ & $\begin{array}{l}\text { Mixed epithelial stromal tumor } \\
\text { Adult nephroblastoma } \\
\text { Papillary RCC } \\
\text { Multiple renal cysts } \\
\text { Renal hamartomas }\end{array}$ & $\begin{array}{l}\text { Hyperparathyroidism } \\
\text { (parathyroid adenoma/carcinoma) }\end{array}$ \\
\hline $\begin{array}{l}\text { PTEN hamartoma tumor } \\
\text { syndrome (Cowden } \\
\text { syndrome) }\end{array}$ & $P T E N$ & $\begin{array}{l}\text { Papilformations } \\
\text { Chromophobe RCC } \\
\text { Prostate carcinoma }\end{array}$ & $\begin{array}{l}\text { Non-medullary thyroid carcinoma } \\
\text { Hashimoto thyroiditis }\end{array}$ \\
\hline
\end{tabular}

RCC: Renal cell carcinoma, CCRCC: Clear cell renal cell carcinoma, PHEO/PGL: Pheochromocytoma/paraganglioma, NETs: neuroendocrine tumors.

3 (3p25-26) (47, 48). This syndrome is characterized by multiple benign and malignant neoplasms in various organs such as kidney, eye, brain, spine, pancreas, and the adrenal. The neoplasia spectrum includes retinal and craniospinal hemangioblastomas; renal, pancreatic and hepatic cysts; adrenal, hepatic, and pulmonary hemangiomas; and solid tumors. Solid tumors include clear cell RCCs, pheochromocytomas, paragangliomas, pancreatic neuroendocrine tumors, endolymphatic sac tumors, epididymal and broad ligament papillary cystadenoma (49). VHL is not rare and accounts for 1 per 36000 live births and the penetrance is $95 \%$ at 65 years of age (49).

The diagnosis of VHL depends on the presence of a family history. A single VHL-associated neoplasm is enough to diagnose VHL if a family history is present. However, cases with de novo mutations do not show a family history. In this setting, at least 2 VHL-associated neoplasms are required for diagnosis $(49,50)$. Genetic counseling should be offered if a suspicion of VHL disease is present. The clinical classification of VHL is based on genotypephenotype correlation. Type 2 VHL differs from Type 1 with the occurrence of pheochromocytoma and is further subdivided according to the risk of RCC (2A: low risk, 2B: high risk, and 2C without RCC) (50).
The protein product of VHL gene, pVHL, regulates HIF1 and HIF-2, which are transcription factors that regulate hypoxia-responsive genes including vascular endothelial growth factor (VEGF), platelet-derived growth factor (PDGFb), transforming growth factor (TGFa) and erythropoietin (51). The VHL gene is inactivated when both alleles are involved (Knudson`s two-hit hypothesis) (52). Inactivation of the VHL gene results in upregulation of HIF$1 \& 2$, which promote angiogenesis and cell proliferation.

Renal tumors in VHL are bilateral, multiple, and accompanied by numerous cystic background lesions $(49,53)$ (Figure 1A-D). Multiple renal tumors and small microscopic foci (tumorlets) are morphologically typical of clear cell RCCs, and renal cysts are lined by flat epithelial cells with clear cytoplasms. The cyst epithelium may show stratification, tufting and papillary structures. These cystic structures showing epithelial changes listed above, are likely to represent early neoplastic transformation (54). Although diagnostic terminology for these cysts has not been standardized, descriptive terms such as "renal cyst with epithelial proliferation" or "renal epithelial cyst with atypia" have been suggested (54). These cystic lesions may mimic clear cell-tubulopapillary RCC in which multilocular masses are confluent, unlike individual cysts of VHL. 


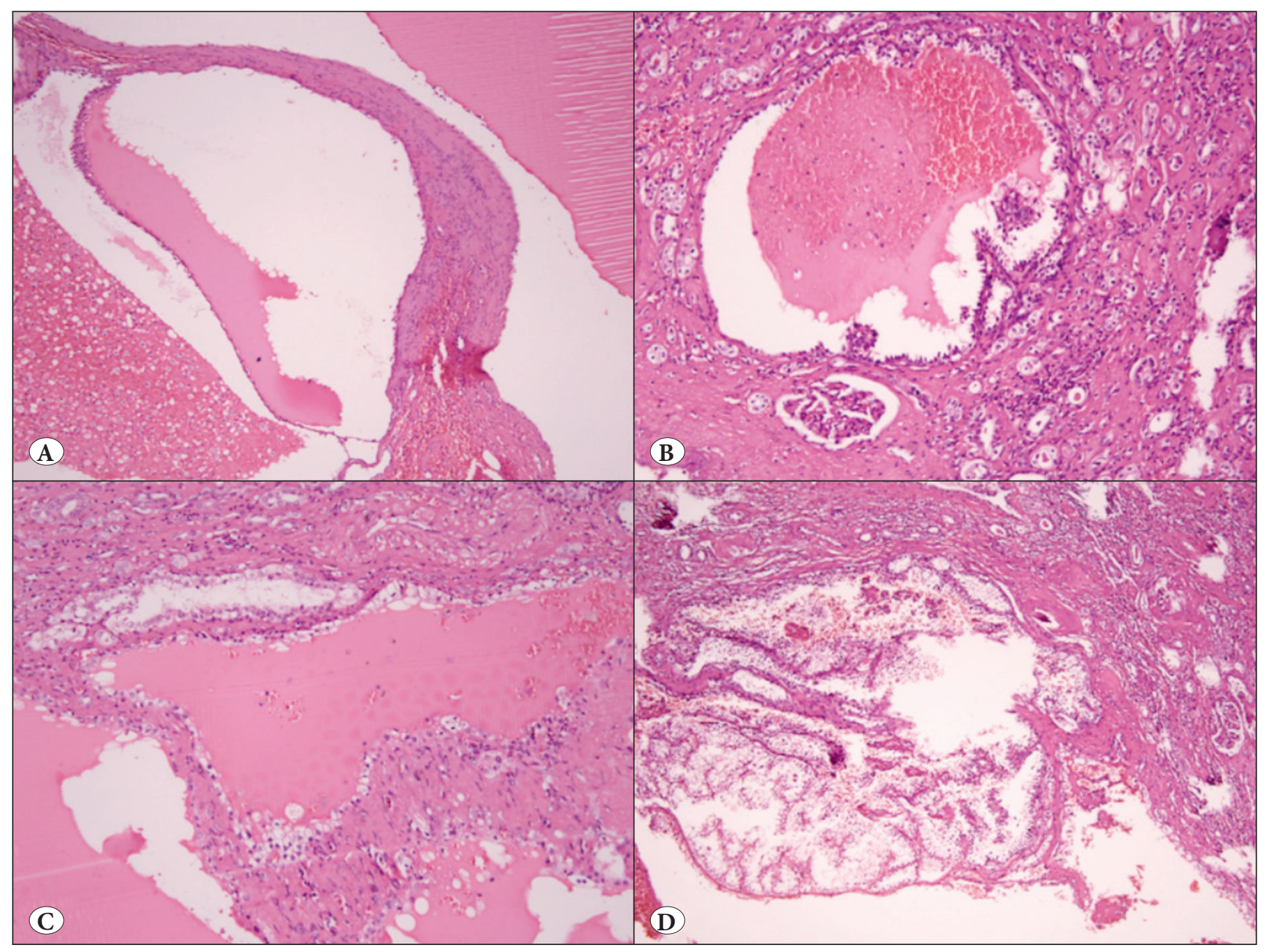

Figure 1: von Hippel Lindau syndrome with multiple cysts and cystic renal cell carcinoma. A) Simple cyst, B) Cyst with papillary proliferations, C) Atypical epithelial cells lining the cyst D) Cystic clear cell renal cell carcinoma ( $\mathrm{H} \& \mathrm{E})$.

The association of sporadic bilateral renal masses with clear cell-tubulopapillary RCC morphology with VHL is the subject of debate (55).

The common endocrine manifestations in VHL include pancreatic neuroendocrine tumors (NETS) and pheochromocytoma/paragangliomas (PHEO/PGL).

Pancreatic NETs account for almost $17 \%$ of patients with VHL $(56,57)$. Like in syndromic form of neoplastic diseases, there are precursor lesions for pancreatic NETs in VHL including nesidioblastosis, islet dysplasia $(<0.5 \mathrm{~mm})$, pancreatic neuroendocrine (endocrine) microadenomas/ adenomatosis $(0.5-5 \mathrm{~mm})$ and peliosis of nontumorous islets (58). The tumor should be at least $0.5 \mathrm{~cm}$ to describe it as a NET. Histologic grading is performed in accordance with the 3-tiered World Health Organization (2010) system regarding the Ki-67 (MIB-1) proliferation index and mitotic activity (59). Morphologically, besides showing characteristic neuroendocrine morphology, these NETs also contain clear cells or multivacuolated lipidrich cells (58). Immunohistochemistry reveals positivity for neuroendocrine markers as well as pancreatic and gastrointestinal hormones $(60,61)$. Inhibin was also shown to be positive in clear cell pancreatic NETS in VHL (60). Clear cell change and inhibin immunoexpression in pancreatic NETs are suggested to be related to HIF1a increase in VHL. VHL is more likely present in cases with multifocal clear cell NETs that express inhibin (60). Pancreatic NETs are malignant, independent of their size or grade (59). Features of local invasiveness, which may lead to life threatening complications, are present in $60 \%$ of pancreatic NETs in VHL (56). Pancreatic cysts and serous cystadenomas may also be present in $17-56 \%$ of the patients with VHL (57, 61). Pancreatic NETs are multiple well-demarcated, brown 
to yellow masses most commonly on a cystic background throughout the pancreas (62). Pancreatic cysts are generally asymptomatic and do not need treatment. The mean age at which neuroendocrine tumors develop is 35 years, whereas for pancreatic NETs is 37 years (53).

Pheochromocytomas are seen in $10-20 \%$ of patients with VHL (63) and the mean age at presentation is 20 years (64). They are multiple and bilateral (65). Although pheochromocytomas are more common in VHL, extraadrenal paragangliomas may also be seen parasympathetic in glomus jugulare, carotid body, and periaortic tissue (66). PHEO/ PGLs in VHL are less likely to present with paroxysmal type of hypertension because they show increased levels of dopamine and norepinephrine (65).

The outcome of VHL depends on NETs whose metastatic risk was reported as 11-17\% (56). Recent development of techniques like nephron-sparing surgery and radiofrequency ablation used for the treatment of RCCs improved the survival related to the renal masses (67).

\section{A2. Birt-Hogg-Dubé (BHD) Syndrome}

BHD is an autosomal dominant syndrome characterized by the occurrence of fibrofolliculomas, lung cysts and spontaneous pneumothorax, and renal cancer (68-70). BHD is seen in approximately 1 per 200000 individuals. Intestinal polyposis $(71,72)$ and medullary thyroid carcinoma (70) in patients with BHD has also been reported. However, the general concensus is that BHD is not associated with intestinal polyps or colonic cancer (73). BHD is overlooked because of its mild variable presentation. The gene for BHD was identified in 2001 in affected families and the gene product was named folliculin (FLCN) (74). Although its function has been controversial, a relation to ciliopathy and involvement in cell polarity, regulation of cell-cell adhesion, and negative regulation of rRNA synthesis was suggested recently (75-77).

Renal tumors seen in BHD are papillary RCC, clear cell RCC, chromophobe RCC, and oncocytoma (78). The underlying renal parenchyma typically shows "renal oncocytosis", which is defined as the presence of diffuse oncocytic changes including dominant oncocytic neoplasm, smaller oncocytic nodules, infiltrating oncocytic cells, cortical cysts lined by oncocytic cells, and oncocytic change in nonneoplastic renal tubules (54). An unusual form of a low-grade oncocytic renal tumor with features of both chromophobe RCC and oncocytoma, called "hybrid oncocytic tumor", is the most common and characteristic tumor for BHD. The most common feature of this tumor is the presence of individual tumor cells with clear cytoplasm without prominent nuclear membrane irregularity. If a patient has a hybrid oncocytic tumor, BHD should be considered (79). The diagnosis for BHD requires at least one major or two of the minor criteria previously defined by Menko et al. to be fulfilled (80). The major criteria are as follows: 1- adult onset at least 5 fibrofolliculomas, one of which is histologically confirmed, 2- FLCN mutation. Minor criteria are: 1- multiple lung cysts, 2- renal cancer (early onset, aged $<50$ years, multifocal/bilateral, hybrid oncocytic morphology), 3- a first degree relative with BHD.

\section{A3. Hereditary Leiomyomatosis RCC (HLRCC) Syndrome}

HLRCC is an autosomal dominant syndrome associated with a germline mutation in fumarate hydratase (FH) gene characterized by cutaneous and uterine leiomyomas in association with RCC (81). The biallelic inactivation of the $\mathrm{FH}$ gene required for the development of HLRCC acts as a tumor suppressor gene (82). Although hereditary renal cancers are mostly multiple and bilateral, RCCs in HLRCC are unilateral and solitary (54). RCCs that occur in HLRCC are frequently high stage and fatal (83). These RCCs strongly resemble type 2 papillary RCCs. Although papillary features are frequently prominent, tubulopapillary, tubular, solid and cystic elements, collecting duct carcinoma-like areas with infiltrating tubules, nests or individual cells in a desmoplastic stroma are also present $(84,85)$. Characteristic morphologic features of tumor cells in HLRCC are the distinct nuclei with prominent eosinophilic nucleoli surrounded by clear halo-like CMV inclusions (85). The striking feature in this syndrome is that tumoral cells of leiomyomas also contain these inclusion-like eosinophilic nucleoli. Cysts lined by epithelial cells that share the same cellular features with HLRCC are reported as precancerous lesions (86). The morphologic spectrum for leiomyomas seen in HLRCC were described as: fascicular growth pattern, staghorn vasculature, cytoplasmic fibrillarity, and characteristic eosinophilic nucleolus surrounded by a perinuclear halo (87-90).

There is no validated marker to determine patients with HLRCC. However, Bardella et al. (91) showed cytoplasmic positivity for $2 \mathrm{SC}$-modified proteins (2SCP) using immunohistochemistry and demonstrated a correct prediction for the mutation in $F H$ gene. The immunopositivity of anti-2SC was explained by succination of cellular proteins due to the accumulation of high levels of fumarate, which form a stable chemical modification, $\mathrm{S}$-(2-succino)-cysteine (2SC). The prospective use of this marker was suggested as a screening method for HLRCC. In a recent study by Chen et al. (84), this antibody was shown to be highly sensitive, and nuclear and cytoplasmic 
Table III: Paraganglioma syndromes and related tumors

\begin{tabular}{|c|c|c|}
\hline PGL Syndrome & Gene & Related tumors of the endocrine and genitourinary systems \\
\hline PGL Type 1 & SDHD & $\begin{array}{l}\text { PHEO/PGL } \\
\text { (head\&neck }>\text { adrenal }>\text { abdominal extraadrenal }>\text { thoracic }) \\
\text { - RCC (very rare) }\end{array}$ \\
\hline PGL Type 2 & SDHAF2 & • Head and neck PGL \\
\hline PGL Type 3 & SDHC & $\begin{array}{l}\text { - Head and neck PGL } \\
\text { - RCC (clear cell, papillary type) } \\
\text { - PHEO (very rare) }\end{array}$ \\
\hline PGL Type 4 & SDHB & $\begin{array}{l}\text { - } \text { PHEO/PGL } \\
\text { (abdominal extraadrenal }>\text { adrenal }>\text { head\&neck }>\text { thoracic) } \\
\text { - RCC }\end{array}$ \\
\hline
\end{tabular}

PGL: Paraganglioma; SDH: Succinate dehydrogenase; PHEO: Pheochromocytoma; RCC: Renal cell carcinoma.

staining was also specific for the diagnosis of HLRCC. In another study performed on uterine leiomyomas related to HLRCC, morphological reproducibility across cases and anti-2SC immunopositivity were demonstrated (90). This antibody is not commercially available and further validation studies are necessary. Identifying patients with HLRCC provides early detection of renal tumors before they become aggressive.

Adrenocortical hyperplasia was reported in a patient with HLRCC with a proven $F H$ mutation (92). The patient had uterine and cutaneous leiomyomas but no renal tumor. ACTH-independent bilateral adrenocortical hyperplasia and clinical Cushing's syndrome was demonstrated. In a retrospective review of 15 patients with adrenocortical hyperplasia and/or HLRCC only 3 patients, including the index case, were detected. However, FH mutation in the tumor DNA was not demonstrated in the other 2 patients. This case report suggests a relationship between adrenocortical hyperplasia and HLRCC. In another recent study by Shuch et al. (93) 7.8\% of HLRCC cases showed unior bilateral adrenal nodular hyperplasia with histologically proven absence of adrenal malignancy.

\section{A4. Familial Paraganglioma and Pheochromocytoma (PGL/PHEO) Syndromes}

Familial PGL syndromes belong to inherited renal syndromes and PHEO/PGL syndromes (94-96). Heritable pheochromocytoma syndromes include neurofibromatosis type I, VHL, multiple endocrine neoplasia type 2, familial PGL syndromes (types 1-4), and familial pheochromocytoma syndromes (TMEM127-gene-associated, MAX-geneassociated and SDHA-gene-associated) (97).

Familial PGL syndromes include adrenal/extraadrenal pheochromocytoma (with high frequency of head and neck
PGL), RCC, thyroid carcinoma, and gastrointestinal stromal tumor (97). At least $30 \%$ of PHEO/PGL are hereditary (98). The gene involved in these 4 types of syndromes is succinate dehydrogenase (SDHB, SDHC, SDHD, SDHAF2) (Table III). SDH, also known as mitochondrial complex 2, is a mitochondrial respiratory enzyme that links the Krebs cycle to the electron transport chain. Double-hit inactivation almost always occurs in the presence of a germline mutation. SDHC and SDHD are anchoring components, whereas SDHA and SDHB are catalytic components. Any doublehit mutation in one of the components makes the entire molecule instable (99). In hypoxic conditions, HIFs provide cell adaptation and survival by inducing several genes on angiogenesis, energy metabolism, survival and growth. The tumorigenesis mechanisms involved in both SDH deficiency and $V H L$ mutation are very similar to hypoxia and have been named as the pseudohypoxic response. Unlike $V H L$ - and $S D H$-related tumors, on the other hand, the underlying mechanisms are reffered to the activation of kinase receptor signaling pathway as in tumors associated with NF1, KIF1BB, TMEM127 and MAX-mutations (99).

SDHB immunohistochemistry is negative in tumor cells in all $S D H$ gene-related tumors but positive in nontumoral cells in a granular (mitochondrial) pattern as an internal control. If SDHB is negative, then SDHA immunohistochemistry should be performed because SDHA and SDHB are both lost in cases with SDHA mutations, whereas SDHA expression is retained in the presence of $S D H B, S D H C$ or SDHD mutations (100). SDH mutations account for almost $15 \%$ of all cases of PHEO/PGL (98). SDHB-driven PHEO/ PGLs show very high malignant potential (99).

Renal neoplasms have been reported in association with germline $S D H$ mutations, $S D H B$ related tumors being the 


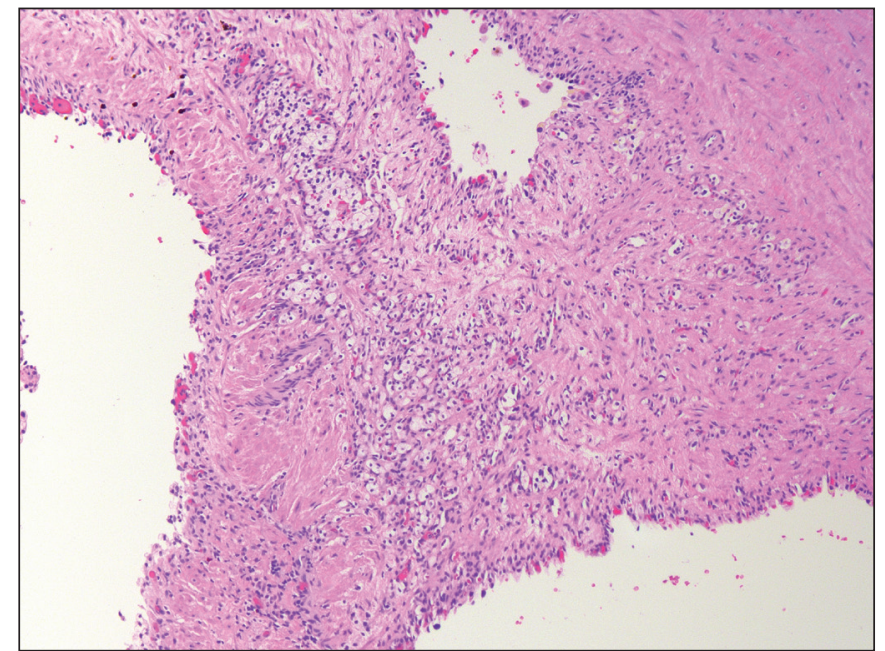

Figure 2: Multilocular cystic tumor diagnosed clear cell renal cell carcinoma from a patient with TMEM127 mutation (HE) (Courtesy of Dr. Ozgur Mete, Guest Editor of this issue, Department of Laboratory Medicine and Pathobiology, University of Toronto, Toronto, Ontario, Canada).

most frequent. SDHC and $S D H D$-related renal tumors are very rare. $S D H B$-deficient RCCs, introduced as a provisional entity in the last Vancouver classification of renal tumors, are well-circumscribed tumors comprised of granular eosinophilic (oncocytic) cells that have intracytoplasmic flocculent eosinophilic inclusions accompanied by intratumoral mast cells $(73,101,102)$. Although this unique morphology is distinctive, it is not present in all cases. The clinical clues are helpful as well as the typical morphology (if present) in SDHB immunohistochemical screening. These clues are bilaterality, multifocality, young-age onset, or a personal or familial history of renal carcinoma or PHEO/ PGL or GIST (99). Germline SDHB mutated RCCs without syndrome-specific features account for $5 \%$ of inherited RCCs (103). Various histopathologic forms of renal tumors may occur including clear cell, papillary, and oncocytoma (104). Genotype-phenotype correlation was detected for $S D H D$ mutations, whereas it could not be shown for $S D H B$. Missense mutations in $S D H D$ gene were associated with a low risk for pheochromocytomas (104).

Germline TMEM127 mutation has been reported in hereditary RCCs (105) and PHEO (106, 107). TMEM127 plays a role in the modulation of endolysosomal function and its mutation activates mTOR pathway (105). The two-hit model of tumor suppressor gene inactivation is present among patients with TMEM127 mutation (108). In contrast to SDHB mutations, TMEM127 mutation-related pheochromocytomas do not exhibit norepinephrine or epinephrine $(106,107)$. Adrenal medullary hyperplasia was a reported endocrine manifestation among patients with TMEM127 mutation-related PHEOs (106). TMEM127 mutation was recently reported in association with cooccurence of PHEO and renal carcinoma (109)(Figure 2). Although genotype-phenotype correlation is often present among hereditary RCCs, a possible correlation for TMEM127-related RCCs is under debate because of the limited number of cases.

\section{A5. Hyperparathyroidism-Jaw Tumor Syndrome (HPT-JTS)}

Hyperparathyroidism-jaw tumor syndrome (HPT-JTS) is a rare autosomal dominant disease related to a germline mutation in CDC73 (also known as HRPT2) tumor suppressor gene encoding parafibromin. There are also some other tumor suppressor genes (TROVE2 and GLRX2) that are also under investigation for HPT-JTS $(110,111)$. HPT-JTS is characterized by the presence of parathyroid neoplasms such as adenoma or carcinoma with associated hyperparathyroidism, fibroosseous lesions (ossifying fibroma) in the mandibula and maxilla, renal cysts, and renal and uterine neoplasms (112). Hyperparathyroidism is mostly associated with parathyroid hyperplasia or adenoma but parathyroid carcinoma is seen in $15 \%$ of patients. Parathyroid carcinoma diagnosis is extremely difficult and depends on the presence of metastasis or local aggressiveness (113). Bone lesions show dense relatively avascular fibroblast-rich stroma, irregular spicules of woven bone with focal rim of osteoblasts (113).

Renal cysts may be numerous and resemble polycystic kidney disease. Renal neoplasms were reported to be mixed epithelial stromal tumor, adult nephroblastoma (Wilms tumor) and papillary RCC (54). Renal hamartomas and uterine carcinomas were also reported in this syndrome (113). Ossifying fibromas are related to the mutation in tumor suppressor gene, but not to hyperparathyroidism (114). Although immunohistochemistry for parafibromin in parathyroid tissue has been reported in HPT-JTS (115), there are no studies regarding renal neoplasms.

\section{A6. PTEN Hamartoma Tumor Syndromes (Cowden Syndrome)(CS)}

PTEN hamartoma tumor syndromes (Cowden syndrome, Bannayan-Riley-Ruvalcaba syndrome, Proteus syndrome, and Proteus-like syndrome), is characterized by multiple hamartomas and breast, thyroid, and endometrial carcinomas, is an autosomal dominant hereditary cancer syndrome associated with a germline mutation in PTENgene $(116,117)$. The diagnosis is made based on the combination of pathognomonic, major and minor criteria as previously described (118). No genotype-phenotype association was 
demonstrated for CS $(119,120)$. The main cancers associated with this syndrome are breast and thyroid carcinomas. The risk for RCC in patients with germline PTEN mutation is increased 31-fold with a CS-RCC penetrance of $4.1 \%$ (119). In another study that included patients with clinical findings highly suggestive of CS, there was $16.7 \%$ penetrance (120). Unlike other hereditary renal syndromes, there is no family history in CS (119). Histologic types of RCC detected in PTEN hamartoma tumor syndrome are $75 \%$ papillary and $25 \%$ chromofobe RCC. No specific morphologic feature is present for this syndrome. Loss of immunohistochemical expression of PTEN has been demonstrated (119). Another genitourinary malignancy reported to be associated with CS is prostate carcinoma in younger patients and this has an aggressive clinical course (121).

Loss of heterozygosity in PTEN is common and leads to activation of the mTOR pathway; targeting this pathway in the treatment has shown clinical benefit (122).

\section{B. Other Hereditary Syndromes with Genitourinary and Endocrine Manifestations}

\section{B1. Carney Complex (CNC)}

$\mathrm{CNC}$ is an autosomal dominant syndrome characterized by spotty skin pigmentation, myxomas and endocrine manifestations (123). Endocrine manifestations include primary pigmented nodular adrenocortical disease (PPNAD) in 25-60\%, large cell calcifying sertoli cell tumor (LCCSCT) in $33-56 \%$ of male patients, acromegaly due to growth hormone secreting pituitary adenoma in $10 \%$, thyroid adenoma or carcinoma in $10-25 \%$ (124, 125). The cause of the disease is inactivating mutations in PKA (proteinkinase A) or PRKAR1A (cAMP-dependent protein kinase) $(126,127)$. In a large cohort of $\mathrm{CNC}$ cases, PRKAR1A mutations were detected in $73 \%$ and were mostly at exons 2, 3, 5, 7, and 8. Genotype-phenotype correlation did not reveal perfect compliance because patients with the same mutations had PPNAD with variable severity (128). However, some associations were determined especially for those mutations resulted in an expression of mutant protein leading to more severe disease (128).

Familial history is present in $70 \%$ of cases, whereas a new germline mutation occurred in 30\% (129). The penetrance of CNC is reported as $70-80 \%$ at 40 years of age (130). The diagnosis of $\mathrm{CNC}$ requires the presence of two of the disease manifestations or if one disease manifestation is present, additional supplemental criteria (such as effected first-degree relative or inactivating mutation in PRKAR1A gene) are needed (124)

PPNAD is the most frequent endocrine manifestation seen in CNC. This entity is the bilateral hyperplasia of adrenal glands that causes Cushing 's syndrome in 30\% of cases (124). Adrenal glands consist of deeply-located, welldemarcated but unencapsulated brown nodules less than $1 \mathrm{~mm}$ in diameter. Lipofuscin is the pigment within the tumor cell cytoplasm that gives the macroscopic brown color. Adrenal glands in PPNAD are normal in size and weight (125). Although normal adrenal cortical cells do not express synaptophysin, PPNAD shows synaptophysin immune reactivity (131). Transformation to adrenocortical carcinoma was also reported in the background of PPNAD (132-134).

Thyroid involvement is also seen in CNC. The lesion spectrum changes from hyperplastic nodules with or without cystic change to carcinomas, either papillary or follicular type $(124,128)$. Most of thyroid tumors are adenomas. Carcinomas are very rare. Patients with PRKAR1A mutation are more likely to have thyroid tumors than those without mutation (128).

LCCSCT are present in one third of males with CNC at presentation. Clinically, these tumors may produce hormones that may cause sexual precocity in young males with low gonadotropin levels, as well as gynecomastia due to aromatase overactivity (135). Infertility is also a feature in $\mathrm{CNC}$ with unclear underlying etiology in which obstruction by the tumor may be a contributory factor (136). LCCSCTs are multifocal and bilateral in $\mathrm{CNC}$ and rarely are sporadic. Tumors show macrocalcifications that can be palpated on physical examination. Grossly, they are well-circumscribed yellowish masses usually less than $4 \mathrm{~cm}$ in diameter. Cystic changes may be present. Calcifications and necrosis can also be found. The tumors are composed of eosinophilic cells within a myxoid to collagenous stroma with neutrophilic infiltration (Figure 3A,B). Tumor cells are arranged in sheets, nests, cords, ribbons, and trabeculae. Usually, focal solid tubule formation is present. Calcifications are usually prominent with large laminated nodule formation. Malignant LCCST is extremely rare; only one case has been reported in CNC (137).

\section{B2. Congenital Adrenal Hyperplasia (CAH)}

$\mathrm{CAH}$ is an autosomal recessive disease related to a defect in cortisol synthesis (138). 21-hydroxylase deficiency is the cause in more than $90 \%$ of the cases (139). Cortisol deficiency results in increased ACTH levels. ACTH stimulation on adrenal cortex leads to overproduction of adrenal androgen precursors. There are two forms of $\mathrm{CAH}$, the classic form with salt wasting and simple virilizing subtypes, and the nonclassic form, which is more frequent. The classic form is severe, whereas the nonclassic form is mild and late onset. Recent developments in treatment strategies of this 

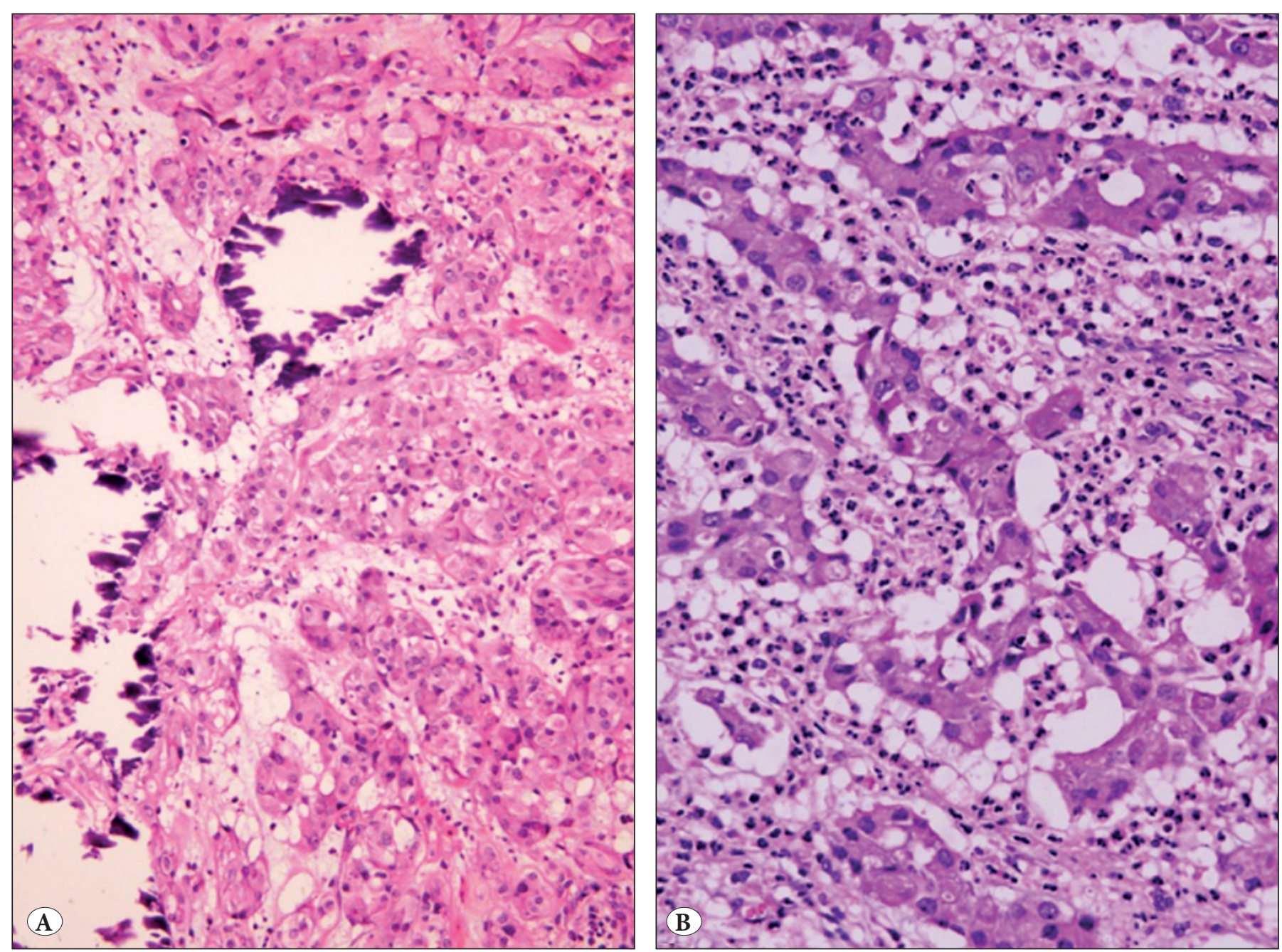

Figure 3: Large cell calcifying Sertoli cell tumor with A) Calcification and prominent neutrophils in the stroma B) Tumor cells arranged in cords, trabecula, and tubules $(\mathrm{H} \& \mathrm{E})$.

syndrome lead to a wide spectrum of patient characteristics from birth to adult life. The pathophysiology, clinical details, and treatment are complex and beyond the scope of this article. Here we will only review testicular adrenal rest tumor related to $\mathrm{CAH}$.

One of the challenging genitourinary and endocrine manifestations of CAH is testicular adrenal rest tumor (TART), which is the most important cause of infertility. TART cause infertility due to both mechanic and paracrine effects (140). They are small tumors that vary from $\mathrm{mm}$ to $\mathrm{cm}$, are mostly bilateral and located close to or within the rete testis. They are palpable if they reach $>2 \mathrm{~cm}$. The gross examination shows yellow-tan multilobular masses. Microscopy resembles that of adrenal cortex. Tumors are well-demarcated but nonencapsulated. Tumor cells have abundant eosinophilic cytoplasm arranged in sheets and cords (Figure 4A,B). Tumor cells are separated by thin fibrovascular septa. Typical zonation of adrenal cortex is absent. Lipofuscin pigment can be seen within the tumor cells (Figure 4C).

TARTs are composed of adrenal-like cells with ACTH and angiotensin II receptors, and also adrenal-specific enzymes and steroids (141). The pathogenesis of TART was investigated through embryology. The adrenal gland and gonad are very close to each other in the embryo and during emigration, some adrenocortical cells may settle in the rete testis (Figure 4B). Increased ACTH concentrations induce these cells to proliferate. Both the concentrations and duration of ACTH exposure determine the tumor development $(142,143)$. The other proposed theory is that hilar pluripotent cells react to increased ACTH production and proliferate (144).

TART and Leydig cell tumors are difficult to differentiate morphologically, the latter have Reinke crystals $25-40 \%$. 


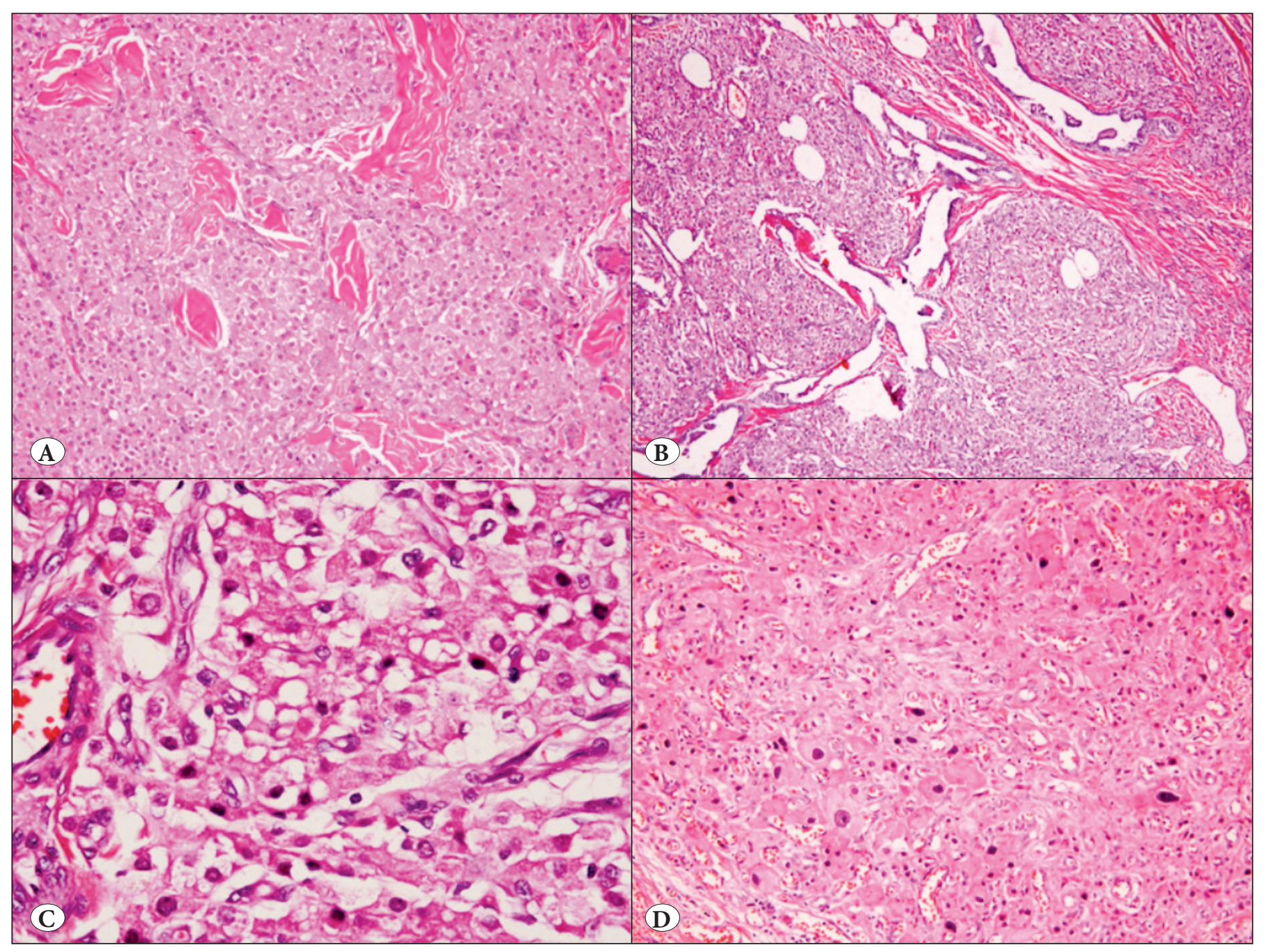

Figure 4: Testicular adrenal rest in a child with congenital adrenal hyperplasia. A) The tumor separated by fibrohyaline bands, B) Localized next to the rete testis, C) Show granular cytoplasm with lipofuscin pigment, D) Focal endocrine atypia (H\&E).

Bilaterality is more frequent in TART, whereas malignant transformation may be seen in Leydig cell tumor but not TART. Lack of cytologic atypia, low mitotic activity, dense fibrous septa, lymphoid aggregates, adipose metaplasia, and lipofuscin pigment favor a diagnosis of TART. However, TART may show endocrine atypia with greater degree of nuclear pleomorphism (145)(Figure 4D). TARTs are positive for CD56, synaptophysin, and negative for androgen receptor. On the other hand, Leydig cell tumors express androgen receptor but show no or weak expression for CD56 and synaptophysin $(145,146)$.

\section{B3. Beckwith-Wiedemann Syndrome (BWS)}

BWS is a pediatric overgrowth syndrome that predisposes to tumor development (147). The hallmarks of BWS are exomphalos, macroglossia, and gigantism. However, not all cases exhibit these features. No sex predilection is present for the frequency of BWS (148). The pathogenesis of BWS is highly complex and thus we should first remember normal status and understand genomic imprinting. Autosomal genes are mostly expressed from both maternal and parental alleles. However, in less than 100 genes the allele from only the parental or maternal allele is expressed. The other allele that is not expressed becomes silenced. This mechanism is called genomic imprinting and is controlled by epigenetic mechanisms such as DNA methylation, histone modification, and noncoding RNAs. This process leads to differences in DNA methylation. These imprinted genes present in clusters called imprinted domains and these are regulated by imprinting centers, which are on the same chromosome. Epigenomic or genomic deregulation of imprinted gene clusters on 11p15.5 region results in BWS (147). This critical region includes various genes: insulinlike growth factor 2 (IGF2), H19, cyclin-dependent kinase 
inhibitor 1C (CDKN1C), potassium channel voltage-gated KQT-like subfamily member 1 (KCNQ1), and KCNQ1overlapping transcript 1 (KCNQ1OT1, or long QT intronic transcript 1). The genetic alterations that occur in BWS are associated with specific phenotype-epigenotype/genotype correlations, which lead to clinical heterogeneity. BWS are usually sporadic ( $80 \%$ ) but autosomal dominant inheritance may be present with a frequency of $15 \%$ (147).

The clinical features of BWS vary and include macroglossia, prenatal and postnatal overgrowth, abdominal wall defects, pancreatic islet hyperplasia (hypoglycemia) (149). The components of the syndrome vary depending on the underlying genetic/epigenetic alterations. Patient types regarding genotype and phenotype are beyond the scope of this article. We only include adrenal and genitourinary tract involvement in this paper. Adrenal cytomegaly is defined as the presence of markedly enlarged cortical cells with eosinophilic cytoplasm. The nuclei are pleomorphic and hyperchromatic. There are intranuclear cytoplasmic pseudoinclusions in the cortical cells. This entity is present in neonates but more common in premature infants with $\mathrm{Rh}$ incompatibility. BWS is another condition in which adrenal cytomegaly is seen. Both adrenal glands are involved and hyperplastic in BWS (149). Adrenal glands are enlarged with a gross cerebriform appearance. Cytomegalic cells are greater in number than isolated adrenal cytomegaly and they mimic CMV infection but lack typical eosinophilic intranuclear inclusions (149). Hemorrhagic adrenal macrocysts may also occur (150). Adrenal adenomas and carcinomas also occur in BWS with increased frequency (151, 152). Various pediatric malignant tumors also develop in patients with BWS such as nephroblastoma (Wilms' tumor), neuroblastoma, and hepatoblastoma. Renal abnormalities like nephromegaly, nephrocalcinosis, and later development of medullary sponge kidney are some other genitourinary tract abnormalities of BWS (149).

\section{CONFLICT OF INTEREST}

The authors have declared no conflict of interest.

\section{REFERENCES}

1. Tiguert R, Fradet Y. Urologic paraneoplastic syndromes. In: Hohenfellner M, Santucci R, editors. Emergencies in urology. Berlin: Springer; 2010.172-82.

2. Sacco E, Pinto F, Sasso F, Racioppi M, Gulino G, Volpe A, Bassi P. Paraneoplastic syndromes in patients with urological malignancies. Urol Int. 2009;83:1-11.

3. Akamatsu S, Takenawa J, Kanamaru S, Soeda A. Ectopic adrenocorticotropic hormone syndrome in a case of small cell carcinoma of the bladder manifesting as severe muscle weakness. Urology. 2006;68:1122.e5-8.
4. Riggs BL, Jr., Sprague RG. Association of Cushing's syndrome and neoplastic disease: Observations in 232 cases of Cushing's syndrome and review of the literature. Arch Intern Med. 1961;108:841-9.

5. Bartuska DG. Humor manifestations of neoplasms. Semin Oncol. 1975;2:405-9.

6. Slater D. Carcinoid tumour of the prostate associated with inappropriate ACTH secretion. Br J Urol. 1985;57:591-2.

7. Kataoka K, Akasaka Y, Nakajima K, Nagao K, Hara H, Miura $\mathrm{K}$, Ishii N. Cushing syndrome associated with prostatic tumor adrenocorticotropic hormone (ACTH) expression after maximal androgen blockade therapy. Int J Urol. 2007;14:436-9.

8. Rickman T, Garmany R, Doherty T, Benson D, Okusa MD. Hypokalemia, metabolic alkalosis, and hypertension: Cushing's syndrome in a patient with metastatic prostate adenocarcinoma. Am J Kidney Dis. 2001;37:838-46.

9. Nimalasena S, Freeman A, Harland S. Paraneoplastic Cushing's syndrome in prostate cancer: A difficult management problem. BJU Int. 2008;101:424-7.

10. Trias I, Algaba F, Condom E, Español I, Seguí J, Orsola I, Villavicencio H, García Del Muro X. Small cell carcinoma of the urinary bladder. Presentation of 23 cases and review of 134 published cases. Eur Urol. 2001;39:85-90.

11. Akashi T, Fuse H, Muraishi Y, Mizuno I, Nagakawa O, Furuya Y. Parathyroid hormone related protein producing penile cancer. J Urol. 2002;167:249.

12. Chaudhary UB, Milling DL, Bissada NK. Transitional cell carcinoma of the bladder producing parathyroid hormonerelated protein (PTHrP). Can J Urol. 2004;11:2136-8.

13. Muggia FM. Overview of cancer-related hypercalcemia: Epidemiology and etiology. Semin Oncol. 1990;17:3-9.

14. Mundy GR, Ibbotson KJ, D’Souza SM, Simpson EL, Jacobs JW, Martin TJ. The hypercalcemia of cancer. Clinical implications and pathogenic mechanisms. N Engl J Med. 1984;310:1718-27.

15. Wolchok JD, Herr HW, Kelly WK. Localized squamous cell carcinoma of the bladder causing hypercalcemia and inhibition of PTH secretion. Urology. 1998;51:489-91.

16. Buckle RM, McMillan M, Mallinson C. Ectopic secretion of parathyroid hormone by a renal adenocarcinoma in a patient with hypercalcaemia. Br Med J. 1970;4:724-6.

17. Dexeus FH, Logothetis CJ, Sella A, Amato R, Kilbourn R, Fitz K, Striegel A. Combination chemotherapy with methotrexate, bleomycin and cisplatin for advanced squamous cell carcinoma of the male genital tract. J Urol. 1991;146:1284-7.

18. Cramer SD, Chen Z, Peehl DM. Prostate specific antigen cleaves parathyroid hormone-related protein in the PTH-like domain: Inactivation of PTHrP-stimulated cAMP accumulation in mouse osteoblasts. J Urol. 1996;156:526-31.

19. Hollifield JW, Page DL, Smith C, Michelakis AM, Staab E, Rhamy R. Renin-secreting clear cell carcinoma of the kidney. Arch Intern Med. 1975;135:859-64.

20. Moein MR, Dehghani VO. Hypertension: A rare presentation of renal cell carcinoma. J Urol. 2000;164:2019. 
21. Lindop GB, Fleming S. Renin in renal cell carcinoma-an immunocytochemical study using an antibody to pure human renin. J Clin Pathol. 1984;37:27-31.

22. Kim HL, Belldegrun AS, Freitas DG, Bui MH, Han KR, Dorey FJ, Figlin RA. Paraneoplastic signs and symptoms of renal cell carcinoma: Implications for prognosis. J Urol. 2003;170:1742-6.

23. Kirchner FK, Jr, Braren V, Smith C, Wilson JP, Foster JH, Hollifield JW, Rhamy RK. Renal carcinoma discovered incidentally by arteriography during evaluation for hypertension. J Urol. 1976;115:643-5.

24. Pavelic K, Popovic M. Insulin and glucagon secretion by renal adenocarcinoma. Cancer. 1981;48:98-100.

25. Callewaert PR, Van Poppel H, Vanderschueren D, Baert L. Uncontrollable diabetes mellitus: A rare paraneoplastic manifestation of renal cell carcinoma. Nephrol Dial Transplant. 1999;14:2263-4.

26. Elias AN. New-onset insulinopenic diabetes mellitus in a patient with an incidentally discovered renal cell carcinoma. Am J Med. 2005;118:1047-8.

27. Palapattu GS, Kristo B, Rajfer J. Paraneoplastic syndromes in urologic malignancy: The many faces of renal cell carcinoma. Rev Urol. 2002;4:163-70.

28. Kenny GM, Mirand EA, Staubitz WJ, Allen JE, Trudel PJ, Murphy GP. Erythropoietin levels in Wilms tumor patients. J Urol. 1970;104:758-61.

29. Murphy GP, Mirand EA, Sinks LF, Allen JE, Staubitz WJ. Ectopic production of erythropoietin in Wilms tumor patients in relation to clinical stage and disease activity. J Urol. 1975;113:230-3.

30. Da Silva JL, Lacombe C, Bruneval P, Casadevall N, Leporrier M, Camilleri JP, Bariety J, Tambourin P, Varet B. Tumor cells are the site of erythropoietin synthesis in human renal cancers associated with polycythemia. Blood. 1990;75:577-82.

31. Wiesener MS, Seyfarth M, Warnecke C, Jürgensen JS, Rosenberger C, Morgan NV, Maher ER, Frei U, Eckardt KU. Paraneoplastic erythrocytosis associated with an inactivating point mutation of the von Hippel-Lindau gene in a renal cell carcinoma. Blood. 2002;99:3562-5.

32. Noguchi Y, Goto T, Yufu Y, Uike N, Hasegawa Y, Fukuda T, Jimi A, Funakoshi A. Gene expression of erythropoietin in renal cell carcinoma. Intern Med. 1999;38:991-4.

33. Rad FH, Ulusakarya A, Gad S, Sibony M, Juin F, Richard S, Machover D, Uzan G. Novel somatic mutations of the VHL gene in an erythropoietin-producing renal carcinoma associated with secondary polycythemia and elevated circulating endothelial progenitor cells. Am J Hematol. 2008;83:155-8.

34. Rankin EB, Tomaszewski JE, Haase VH. Renal cyst development in mice with conditional inactivation of the von Hippel-Lindau tumor suppressor. Cancer Res. 2006;66:2576-83.

35. Kim WY, Kaelin WG. Role of VHL gene mutation in human cancer. J Clin Oncol. 2004;22:4991-5004.

36. Morais C, Johnson DW, Vesey DA, Gobe GC. Functional significance of erythropoietin in renal cell carcinoma. BMC Cancer. 2013;13:14.
37. Michael A, Politi E, Havranek E, Corbishley C, Karapanagiotou L, Anderson C, Relph K, Syrigos KN, Pandha H. Prognostic significance of erythropoietin expression in human renal cell carcinoma. BJU Int. 2007;100:291-4.

38. Lee YS, Vortmeyer AO, Lubensky IA, Vogel TW, Ikejiri B, Ferlicot S, Benoît G, Giraud S, Oldfield EH, Linehan WM, Teh BT, Richard S, Zhuang Z. Coexpression of erythropoietin and erythropoietin receptor in von Hippel-Lindau diseaseassociated renal cysts and renal cell carcinoma. Clin Cancer Res. 2005;11:1059-64

39. Gross AJ, Wolff M, Fandrey J, Miersch WD, Dieckmann KP, Jelkmann W. Prevalence of paraneoplastic erythropoietin production by renal cell carcinomas. Clin Investig. 1994;72:33740.

40. Fukutani K, Libby JM, Panko WB, Scardino PT. Human chorionic gonadotropin detected in urinary concentrates from patients with malignant tumors of the testis, prostate, bladder, ureter and kidney. J Urol. 1983;129:74-7.

41. Smith DM, McKenna K, Thompson CJ. Hyponatraemia. Clin Endocrinol (Oxf). 2000;52:667-78.

42. Yamazaki T, Suzuki H, Tobe T, Sekita N, Kito H, Ichikawa $\mathrm{T}$, Akakura $\mathrm{K}$, Igarashi $\mathrm{T}$, Ito $\mathrm{H}$. Prostate adenocarcinoma producing syndrome of inappropriate secretion of antidiuretic hormone. Int J Urol. 2001;8:513-6.

43. Ghandur-Mnaymneh L, Satterfield S, Block NL. Small cell carcinoma of the prostate gland with inappropriate antidiuretic hormone secretion: Morphological, immunohistochemical and clinical expressions. J Urol. 1986;135:1263-6.

44. Kawai S, Hiroshima K, Tsukamoto Y, Tobe T, Suzuki H, Ito $\mathrm{H}$, Ohwada $\mathrm{H}$, Ito $\mathrm{H}$. Small cell carcinoma of the prostate expressing prostate-specific antigen and showing syndrome of inappropriate secretion of antidiuretic hormone: An autopsy case report. Pathol Int. 2003;53:892-6.

45. Kaye SB, Ross EJ. Inappropriate anti-diuretic hormone (ADH) secretion in association with carcinoma of the bladder. Postgrad Med J. 1977;53:274-6.

46. Tamura T, Takeuchi K. Small cell gall bladder carcinoma complicated by syndrome of inappropriate secretion of antidiuretic hormone (SIADH) treated with mozavaptan. BMJ Case Rep. 2013;2013.

47. Clifford SC, Maher ER. Von Hippel-Lindau disease: Clinical and molecular perspectives. Adv Cancer Res. 2001;82:85-105.

48. Latif F, Tory K, Gnarra J, Yao M, Duh FM, Orcutt ML, Stackhouse T, Kuzmin I, Modi W, Geil L. Identification of the von HippelLindau disease tumor suppressor gene. Science. 1993;260:131720.

49. Maher ER, Neumann HP, Richard S. von Hippel-Lindau disease: A clinical and scientific review. Eur J Hum Genet. 2011;19:61723.

50. Barontini M, Dahia PL. VHL disease. Best Pract Res Clin Endocrinol Metab. 2010;24:401-13.

51. Cockman ME, Masson N, Mole DR, Jaakkola P, Chang GW, Clifford SC, Maher ER, Pugh CW, Ratcliffe PJ, Maxwell PH. Hypoxia inducible factor-alpha binding and ubiquitylation by the von Hippel-Lindau tumor suppressor protein. J Biol Chem. 2000;275:25733-41. 
52. Knudson AG, Jr. Genetics of human cancer. Annu Rev Genet. 1986;20:231-51.

53. Lonser RR, Glenn GM, Walther M, Chew EY, Libutti SK, Linehan WM, Oldfield EH. von Hippel-Lindau disease. Lancet. 2003;361:2059-67.

54. Przybycin CG, Magi-Galluzzi C, McKenney JK. Hereditary syndromes with associated renal neoplasia: A practical guide to histologic recognition in renal tumor resection specimens. Adv Anat Pathol. 2013;20:245-63.

55. Aydin H, Chen L, Cheng L, Vaziri S, He H, Ganapathi R, Delahunt B, Magi-Galluzzi C, Zhou M. Clear cell tubulopapillary renal cell carcinoma: A study of 36 distinctive low-grade epithelial tumors of the kidney. Am J Surg Pathol. 2010;34:1608-21.

56. Corcos O, Couvelard A, Giraud S, Vullierme MP, Dermot O’Toole, Rebours V, Stievenart JL, Penfornis A, Niccoli-Sire P, Baudin E, Sauvanet A, Levy P, Ruszniewski P, Richard S, Hammel P. Endocrine pancreatic tumors in von Hippel-Lindau disease: Clinical, histological, and genetic features. Pancreas. 2008;37:8593.

57. Libutti SK, Choyke PL, Bartlett DL, Vargas H, Walther M, Lubensky I, Glenn G, Linehan WM, Alexander HR. Pancreatic neuroendocrine tumors associated with von Hippel Lindau disease: Diagnostic and management recommendations. Surgery. 1998;124:1153-9.

58. Mete O, Asa SL. Precursor lesions of endocrine system neoplasms. Pathology. 2013;45:316-30.

59. WHO classification of tumors of the digestive system. Bosman F, Carneiro F, Hruban R, Theise N, editors. 4th ed. Lyon,France: IARC Press; 2010.

60. Gucer H, Szentgyorgyi E, Ezzat S, Asa SL, Mete O. Inhibinexpressing clear cell neuroendocrine tumor of the ampulla: An unusual presentation of von Hippel-Lindau disease. Virchows Arch. 2013;463:593-7.

61. Lubensky IA, Pack S, Ault D, Vortmeyer AO, Libutti SK, Choyke PL, Walther MM, Linehan WM, Zhuang Z. Multiple neuroendocrine tumors of the pancreas in von Hippel-Lindau disease patients: Histopathological and molecular genetic analysis. Am J Pathol. 1998;153:223-31.

62. Cassol C, Mete O. Endocrine manifestations of von HippelLindau disease. Arch Pathol Lab Med. 2015;139:263-8.

63. Walther MM, Reiter R, Keiser HR, Choyke PL, Venzon D, Hurley K, Gnarra JR, Reynolds JC, Glenn GM, Zbar B, Linehan WM. Clinical and genetic characterization of pheochromocytoma in von Hippel-Lindau families: Comparison with sporadic pheochromocytoma gives insight into natural history of pheochromocytoma. J Urol. 1999;162:659-64.

64. Woodward ER, Maher ER. Von Hippel-Lindau disease and endocrine tumour susceptibility. Endocr Relat Cancer. 2006;13:415-25.

65. Eisenhofer G, Walther MM, Huynh TT, Li ST, Bornstein SR, Vortmeyer A, Mannelli M, Goldstein DS, Linehan WM, Lenders JW, Pacak K. Pheochromocytomas in von Hippel-Lindau syndrome and multiple endocrine neoplasia type 2 display distinct biochemical and clinical phenotypes. J Clin Endocrinol Metab. 2001;86:1999-2008.
66. Gaal J, van Nederveen FH, Erlic Z, Korpershoek E, Oldenburg R, Boedeker CC, Kontny U, Neumann HP, Dinjens WN, de Krijger RR. Parasympathetic paragangliomas are part of the Von HippelLindau syndrome. J Clin Endocrinol Metab. 2009;94:4367-71.

67. Shuin T, Yamasaki I, Tamura K, Okuda H, Furihata M, Ashida S. Von Hippel-Lindau disease: Molecular pathological basis, clinical criteria, genetic testing, clinical features of tumors and treatment. Jpn J Clin Oncol. 2006;36:337-43.

68. Khoo SK, Bradley M, Wong FK, Hedblad MA, Nordenskjold M, Teh BT. Birt-Hogg-Dube syndrome: Mapping of a novel hereditary neoplasia gene to chromosome 17p12-q11.2. Oncogene. 2001;20:5239-42.

69. Schmidt LS, Warren MB, Nickerson ML, Weirich G, Matrosova V, Toro JR, Turner ML, Duray P, Merino M, Hewitt S, Pavlovich CP, Glenn G, Greenberg CR, Linehan WM, Zbar B. Birt-HoggDube syndrome, a genodermatosis associated with spontaneous pneumothorax and kidney neoplasia, maps to chromosome 17p11.2. Am J Hum Genet. 2001;69:876-82.

70. Birt AR, Hogg GR, Dube WJ. Hereditary multiple fibrofolliculomas with trichodiscomas and acrochordons. Arch Dermatol. 1977;113:1674-7.

71. Rongioletti F, Hazini R, Gianotti G, Rebora A. Fibrofolliculomas, tricodiscomas and acrochordons (Birt-Hogg-Dube) associated with intestinal polyposis. Clin Exp Dermatol. 1989;14:72-4.

72. Hornstein OP, Knickenberg M. Perifollicular fibromatosis cutis with polyps of the colon--a cutaneo-intestinal syndrome sui generis. Arch Dermatol Res. 1975;253:161-75.

73. Srigley JR, Delahunt B, Eble JN, Egevad L, Epstein JI, Grignon D, Hes O, Moch H, Montironi R, Tickoo SK, Zhou M, Argani P; ISUP Renal Tumor Panel. The International Society of Urological Pathology (ISUP) Vancouver Classification of Renal Neoplasia. Am J Surg Pathol. 2013;37:1469-89.

74. Nickerson ML, Warren MB, Toro JR, Matrosova V, Glenn G, Turner ML, Duray P, Merino M, Choyke P, Pavlovich CP, Sharma N, Walther M, Munroe D, Hill R, Maher E, Greenberg C, Lerman MI, Linehan WM, Zbar B, Schmidt LS. Mutations in a novel gene lead to kidney tumors, lung wall defects, and benign tumors of the hair follicle in patients with the Birt-Hogg-Dube syndrome. Cancer Cell. 2002;2:157-64.

75. Luijten MN, Basten SG, Claessens T, Vernooij M, Scott CL, Janssen R, Easton JA, Kamps MA, Vreeburg M, Broers JL, van Geel M, Menko FH, Harbottle RP, Nookala RK, Tee AR, Land SC, Giles RH, Coull BJ, van Steensel MA. Birt-Hogg-Dube syndrome is a novel ciliopathy. Hum Mol Genet. 2013;22:438397.

76. Gaur K, Li J, Wang D, Dutta P, Yan SJ, Tsurumi A, Land H, Wu G, Li WX. The Birt-Hogg-Dube tumor suppressor Folliculin negatively regulates ribosomal RNA synthesis. Hum Mol Genet. 2013;22:284-99.

77. Medvetz DA, Khabibullin D, Hariharan V, Ongusaha PP, Goncharova EA, Schlechter T, Darling TN, Hofmann I, Krymskaya VP, Liao JK, Huang H, Henske EP. Folliculin, the product of the Birt-Hogg-Dube tumor suppressor gene, interacts with the adherens junction protein p0071 to regulate cell-cell adhesion. PLoS One. 2012;7:e47842. 
78. Pavlovich CP, Grubb RL 3rd, Hurley K, Glenn GM, Toro J, Schmidt LS, Torres-Cabala C, Merino MJ, Zbar B, Choyke P, Walther MM, Linehan WM. Evaluation and management of renal tumors in the Birt-Hogg-Dube syndrome. J Urol. 2005;173:1482-6.

79. Haas NB, Nathanson KL. Hereditary kidney cancer syndromes. Adv Chronic Kidney Dis. 2014;21:81-90.

80. Menko FH, van Steensel MA, Giraud S, Friis-Hansen L, Richard S, Ungari S, Nordenskjöld M, Hansen TV, Solly J, Maher ER; European BHD Consortium. Birt-Hogg-Dube syndrome: Diagnosis and management. Lancet Oncol. 2009;10:1199-206.

81. Launonen V, Vierimaa O, Kiuru M, Isola J, Roth S, Pukkala E, Sistonen P, Herva R, Aaltonen LA. Inherited susceptibility to uterine leiomyomas and renal cell cancer. Proc Natl Acad Sci U S A. 2001;98:3387-92.

82. Tomlinson IP, Alam NA, Rowan AJ, Barclay E, Jaeger EE, Kelsell D, Leigh I, Gorman P, Lamlum H, Rahman S, Roylance RR, Olpin S, Bevan S, Barker K, Hearle N, Houlston RS, Kiuru M, Lehtonen R, Karhu A, Vilkki S, Laiho P, Eklund C, Vierimaa O, Aittomäki K, Hietala M, Sistonen P, Paetau A, Salovaara R, Herva $\mathrm{R}$, Launonen V, Aaltonen LA; Multiple Leiomyoma Consortium. Germline mutations in $\mathrm{FH}$ predispose to dominantly inherited uterine fibroids, skin leiomyomata and papillary renal cell cancer. Nat Genet. 2002;30:406-10.

83. Grubb RL, 3rd, Franks ME, Toro J, Middelton L, Choyke L, Fowler S, Torres-Cabala C, Glenn GM, Choyke P, Merino MJ, Zbar B, Pinto PA, Srinivasan R, Coleman JA, Linehan WM. Hereditary leiomyomatosis and renal cell cancer: A syndrome associated with an aggressive form of inherited renal cancer. J Urol. 2007;177:2074-9; discussion 9-80.

84. Chen YB, Brannon AR, Toubaji A, Dudas ME, Won HH, AlAhmadie HA, Fine SW, Gopalan A, Frizzell N, Voss MH, Russo P, Berger MF, Tickoo SK, Reuter VE. Hereditary leiomyomatosis and renal cell carcinoma syndrome-associated renal cancer: Recognition of the syndrome by pathologic features and the utility of detecting aberrant succination by immunohistochemistry. Am J Surg Pathol. 2014;38:627-37.

85. Merino MJ, Torres-Cabala C, Pinto P, Linehan WM. The morphologic spectrum of kidney tumors in hereditary leiomyomatosis and renal cell carcinoma (HLRCC) syndrome. Am J Surg Pathol. 2007;31:1578-85.

86. Ghosh A, Merino M, Linehan M. Are cysts the precancerous lesion in HLRCC? The morphologic spectrum of premalignant lesions and associated molecular changes in hereditary renal cell carcinoma: Their clinical significance. Mod Pathol. 2013;26:212A.

87. Sanz-Ortega J, Vocke C, Stratton P, Linehan WM, Merino MJ. Morphologic and molecular characteristics of uterine leiomyomas in hereditary leiomyomatosis and renal cancer (HLRCC) syndrome. Am J Surg Pathol. 2013;37:74-80.

88. Garg K, Tickoo SK, Soslow RA, Reuter VE. Morphologic features of uterine leiomyomas associated with hereditary leiomyomatosis and renal cell carcinoma syndrome: A case report. Am J Surg Pathol. 2011;35:1235-7.
89. Martinek P, Grossmann P, Hes O, Bouda J, Eret V, Frizzell N, Gill AJ, Ondič O. Genetic testing of leiomyoma tissue in women younger than 30 years old might provide an effective screening approach for the hereditary leiomyomatosis and renal cell cancer syndrome (HLRCC). Virchows Arch. May 2015. (Epub ahead of print)

90. Reyes C, Karamurzin Y, Frizzell N, Garg K, Nonaka D, Chen YB, Soslow RA. Uterine smooth muscle tumors with features suggesting fumarate hydratase aberration: Detailed morphologic analysis and correlation with S-(2-succino)-cysteine immunohistochemistry. Mod Pathol. 2014;27:1020-7.

91. Bardella C, El-Bahrawy M, Frizzell N, Adam J, Ternette N, Hatipoglu E, Howarth K, O’Flaherty L, Roberts I, Turner G, Taylor J, Giaslakiotis K, Macaulay VM, Harris AL, Chandra A, Lehtonen HJ, Launonen V, Aaltonen LA, Pugh CW, Mihai R, Trudgian D, Kessler B, Baynes JW, Ratcliffe PJ, Tomlinson IP, Pollard PJ. Aberrant succination of proteins in fumarate hydratase-deficient mice and HLRCC patients is a robust biomarker of mutation status. J Pathol. 2011;225:4-11.

92. Matyakhina L, Freedman RJ, Bourdeau I, Wei MH, Stergiopoulos SG, Chidakel A, Walther M, Abu-Asab M, Tsokos M, Keil M, Toro J, Linehan WM, Stratakis CA. Hereditary leiomyomatosis associated with bilateral, massive, macronodular adrenocortical disease and atypical cushing syndrome: A clinical and molecular genetic investigation. J Clin Endocrinol Metab. 2005;90:3773-9.

93. Shuch B, Ricketts CJ, Vocke CD, Valera VA, Chen CC, Gautam R, Gupta GN, Gomez Macias GS, Merino MJ, Bratslavsky G, Linehan WM. Adrenal nodular hyperplasia in hereditary leiomyomatosis and renal cell cancer. J Urol. 2013;189:430-5.

94. Bayley JP, Kunst HP, Cascon A, Sampietro ML, Gaal J, Korpershoek E, Hinojar-Gutierrez A, Timmers HJ, Hoefsloot LH, Hermsen MA, Suárez C, Hussain AK, Vriends AH, Hes FJ, Jansen JC, Tops CM, Corssmit EP, de Knijff P, Lenders JW, Cremers CW, Devilee P, Dinjens WN, de Krijger RR, Robledo M. SDHAF2 mutations in familial and sporadic paraganglioma and phaeochromocytoma. Lancet Oncol. 2010;11:366-72.

95. Neumann HP, Pawlu C, Peczkowska M, Bausch B, McWhinney SR, Muresan M, Buchta M, Franke G, Klisch J, Bley TA, Hoegerle S, Boedeker CC, Opocher G, Schipper J, Januszewicz A, Eng C; European-American Paraganglioma Study Group. Distinct clinical features of paraganglioma syndromes associated with SDHB and SDHD gene mutations. JAMA. 2004;292:943-51.

96. Schiavi F, Savvoukidis T, Trabalzini F, Grego F, Piazza M, Amistà P, Demattè S, Del Piano A, Cecchini ME, Erlic Z, De Lazzari P, Mantero F, Opocher G. Paraganglioma syndrome: SDHB, SDHC, and SDHD mutations in head and neck paragangliomas. Ann N Y Acad Sci. 2006;1073:190-7.

97. Bausch B, Jilg C, Gläsker S, Vortmeyer A, Lützen N, Anton A, Eng C, Neumann HP. Renal cancer in von Hippel-Lindau disease and related syndromes. Nat Rev Nephrol. 2013;9:529-38.

98. Gill AJ, Benn DE, Chou A, Clarkson A, Muljono A, MeyerRochow GY, Richardson AL, Sidhu SB, Robinson BG, CliftonBligh RJ. Immunohistochemistry for SDHB triages genetic testing of SDHB, SDHC, and SDHD in paragangliomapheochromocytoma syndromes. Hum Pathol. 2010;41:805-14.

99. Gill AJ. Succinate dehydrogenase (SDH) and mitochondrial driven neoplasia. Pathology. 2012;44:285-92. 
100. Korpershoek E, Favier J, Gaal J, Burnichon N, van Gessel B, Oudijk L, Badoual C, Gadessaud N, Venisse A, Bayley JP, van Dooren MF, de Herder WW, Tissier F, Plouin PF, van Nederveen FH, Dinjens WN, Gimenez-Roqueplo AP, de Krijger RR. SDHA immunohistochemistry detects germline SDHA gene mutations in apparently sporadic paragangliomas and pheochromocytomas. J Clin Endocrinol Metab. 2011;96:E14726.

101. Gill AJ, Pachter NS, Chou A, Young B, Clarkson A, Tucker KM, Winship IM, Earls P, Benn DE, Robinson BG, Fleming S, CliftonBligh RJ. Renal tumors associated with germline SDHB mutation show distinctive morphology. Am J Surg Pathol. 2011;35:157885.

102. Williamson SR, Eble JN, Amin MB, Gupta NS, Smith SC, Sholl LM, Montironi R, Hirsch MS, Hornick JL. Succinate dehydrogenase-deficient renal cell carcinoma: Detailed characterization of 11 tumors defining a unique subtype of renal cell carcinoma. Mod Pathol. 2015;28:80-94.

103. Ricketts C, Woodward ER, Killick P, Morris MR, Astuti D, Latif F, Maher ER. Germline SDHB mutations and familial renal cell carcinoma. J Natl Cancer Inst. 2008;100:1260-2.

104. Ricketts CJ, Forman JR, Rattenberry E, Bradshaw N, Lalloo F, Izatt L, Cole TR, Armstrong R, Kumar VK, Morrison PJ, Atkinson AB, Douglas F, Ball SG, Cook J, Srirangalingam U, Killick P, Kirby G, Aylwin S, Woodward ER, Evans DG, Hodgson SV, Murday V, Chew SL, Connell JM, Blundell TL, Macdonald F, Maher ER. Tumor risks and genotype-phenotype-proteotype analysis in 358 patients with germline mutations in SDHB and SDHD. Hum Mutat. 2010;31:41-51.

105. Qin Y, Deng Y, Ricketts CJ, Srikantan S, Wang E, Maher ER, Dahia PL. The tumor susceptibility gene TMEM127 is mutated in renal cell carcinomas and modulates endolysosomal function. Hum Mol Genet. 2014;23:2428-39.

106. Toledo SP, Lourenço DM Jr, Sekiya T, Lucon AM, Baena ME, Castro CC, Bortolotto LA, Zerbini MC, Siqueira SA, Toledo RA, Dahia PL. Penetrance and clinical features of pheochromocytoma in a six-generation family carrying a germline TMEM127 mutation. J Clin Endocrinol Metab. 2015;100:E308-18.

107. Yao L, Schiavi F, Cascon A, Qin Y, Inglada-Pérez L, King EE, Toledo RA, Ercolino T, Rapizzi E, Ricketts CJ, Mori L, Giacchè M, Mendola A, Taschin E, Boaretto F, Loli P, Iacobone M, Rossi GP, Biondi B, Lima-Junior JV, Kater CE, Bex M, Vikkula M, Grossman AB, Gruber SB, Barontini M, Persu A, Castellano M, Toledo SP, Maher ER, Mannelli M, Opocher G, Robledo M, Dahia PL. Spectrum and prevalence of FP/TMEM127 gene mutations in pheochromocytomas and paragangliomas. JAMA. 2010;304:2611-9.

108. Burnichon N, Lepoutre-Lussey C, Laffaire J, Gadessaud N, Molinié V, Hernigou A, Plouin PF, Jeunemaitre X, Favier J, Gimenez-Roqueplo AP. A novel TMEM127 mutation in a patient with familial bilateral pheochromocytoma. Eur J Endocrinol. 2011;164:141-5.

109. Hernandez KG, Ezzat S, Morel CF, Swallow C, Otremba M, Dickson BC, Asa SL, Mete O. Familial pheochromocytoma and renal cell carcinoma syndrome: TMEM127 as a novel candidate gene for the association. Virchows Arch. 2015;466:727-32.
110. Cascon A, Huarte-Mendicoa CV, Javier Leandro-García L, Letón R, Suela J, Santana A, Costa MB, Comino-Méndez I, Landa I, Sánchez L, Rodríguez-Antona C, Cigudosa JC, Robledo M. Detection of the first gross CDC73 germline deletion in an HPTJT syndrome family. Genes Chromosomes Cancer. 2011;50:922-9.

111. de Mesquita Netto AC, Gomez RS, Diniz MG, Fonseca-Silva T, Campos K, De Marco L, Carlos R, Gomes CC. Assessing the contribution of HRPT2 to the pathogenesis of jaw fibrous dysplasia, ossifying fibroma, and osteosarcoma. Oral Surg Oral Med Oral Pathol Oral Radiol. 2013;115:359-67.

112. Jackson CE, Norum RA, Boyd SB, Talpos GB, Wilson SD, Taggart RT, Mallette LE. Hereditary hyperparathyroidism and multiple ossifying jaw fibromas: A clinically and genetically distinct syndrome. Surgery. 1990;108:1006-12; discussion 12-3.

113. Chen JD, Morrison C, Zhang C, Kahnoski K, Carpten JD, Teh BT. Hyperparathyroidism-jaw tumour syndrome. J Intern Med. 2003;253:634-42.

114. Parfitt J, Harris M, Wright JM, Kalamchi S. Tumor suppressor gene mutation in a patient with a history of hyperparathyroidismjaw tumor syndrome and healed generalized osteitis fibrosa cystica: A case report and genetic pathophysiology review. J Oral Maxillofac Surg. 2015;73:194 e1-9.

115. Gill AJ, Clarkson A, Gimm O, Keil J, Dralle H, Howell VM, Marsh DJ. Loss of nuclear expression of parafibromin distinguishes parathyroid carcinomas and hyperparathyroidismjaw tumor (HPT-JT) syndrome-related adenomas from sporadic parathyroid adenomas and hyperplasias. Am J Surg Pathol. 2006;30:1140-9.

116. Eng C. PTEN: One gene, many syndromes. Hum Mutat. 2003;22:183-98.

117. Eng C. Will the real Cowden syndrome please stand up: Revised diagnostic criteria. J Med Genet. 2000;37:828-30.

118. Pilarski R, Eng C. Will the real Cowden syndrome please stand up (again)? Expanding mutational and clinical spectra of the PTEN hamartoma tumour syndrome. J Med Genet. 2004;41:323-6.

119. Mester JL, Zhou M, Prescott N, Eng C. Papillary renal cell carcinoma is associated with PTEN hamartoma tumor syndrome. Urology. 2012;79:1187.e1-7.

120. Shuch B, Ricketts CJ, Vocke CD, Komiya T, Middelton LA, Kauffman EC, Merino MJ, Metwalli AR, Dennis P, Linehan WM. Germline PTEN mutation Cowden syndrome: An underappreciated form of hereditary kidney cancer. J Urol. 2013;190:1990-8.

121. Barbosa M, Henrique M, Pinto-Basto J, Claes K, Soares G. Prostate cancer in Cowden syndrome: Somatic loss and germline mutation of the PTEN gene. Cancer Genet. 2011;204:224-5.

122. Cho D, Signoretti S, Dabora S, Regan M, Seeley A, Mariotti M, Youmans A, Polivy A, Mandato L, McDermott D, Stanbridge E, Atkins M. Potential histologic and molecular predictors of response to temsirolimus in patients with advanced renal cell carcinoma. Clin Genitourin Cancer. 2007;5:379-85.

123. Carney JA, Gordon H, Carpenter PC, Shenoy BV, Go VL. The complex of myxomas, spotty pigmentation, and endocrine overactivity. Medicine (Baltimore). 1985;64:270-83.

124. Stratakis CA, Kirschner LS, Carney JA. Clinical and molecular features of the Carney complex: Diagnostic criteria and recommendations for patient evaluation. J Clin Endocrinol Metab. 2001;86:4041-6. 
125. Bertherat J. Carney complex (CNC). Orphanet J Rare Dis 2006; $1: 21$

126. Kirschner LS, Carney JA, Pack SD, Taymans SE, Giatzakis C, Cho YS, Cho-Chung YS, Stratakis CA. Mutations of the gene encoding the protein kinase A type I-alpha regulatory subunit in patients with the Carney complex. Nat Genet. 2000;26:89-92.

127. Kirschner LS, Sandrini F, Monbo J, Lin JP, Carney JA, Stratakis CA. Genetic heterogeneity and spectrum of mutations of the PRKAR1A gene in patients with the carney complex. Hum Mol Genet. 2000;9:3037-46.

128. Bertherat J, Horvath A, Groussin L, Grabar S, Boikos S, Cazabat L, Libe R, René-Corail F, Stergiopoulos S, Bourdeau I, Bei T, Clauser E, Calender A, Kirschner LS, Bertagna X, Carney JA, Stratakis CA. Mutations in regulatory subunit type 1A of cyclic adenosine 5'-monophosphate-dependent protein kinase (PRKAR1A): Phenotype analysis in 353 patients and 80 different genotypes. J Clin Endocrinol Metab. 2009;94:2085-91.

129. Espiard S, Bertherat J. Carney complex. Front Horm Res. 2013;41:50-62.

130. Casey M, Mah C, Merliss AD, Kirschner LS, Taymans SE, Denio AE, Korf B, Irvine AD, Hughes A, Carney JA, Stratakis CA, Basson CT. Identification of a novel genetic locus for familial cardiac myxomas and Carney complex. Circulation. 1998;98:2560-6.

131. Stratakis CA, Carney JA, Kirschner LS, Willenberg HS, Brauer S, Ehrhart-Bornstein M, Bornstein SR. Synaptophysin immunoreactivity in primary pigmented nodular adrenocortical disease: Neuroendocrine properties of tumors associated with Carney complex. J Clin Endocrinol Metab. 1999;84:1122-8.

132. Anselmo J, Medeiros S, Carneiro V, Greene E, Levy I, Nesterova M, Lyssikatos C, Horvath A, Carney JA, Stratakis CA. A large family with Carney complex caused by the S147G PRKAR1A mutation shows a unique spectrum of disease including adrenocortical cancer. J Clin Endocrinol Metab. 2012;97:351-9.

133. Morin E, Mete O, Wasserman JD, Joshua AM, Asa SL, Ezzat S. Carney complex with adrenal cortical carcinoma. J Clin Endocrinol Metab. 2012;97:E202-6.

134. Bertherat J. Adrenocortical cancer in Carney complex: A paradigm of endocrine tumor progression or an association of genetic predisposing factors? J Clin Endocrinol Metab. 2012;97:387-90.

135. Gourgari E, Saloustros E, Stratakis CA. Large-cell calcifying Sertoli cell tumors of the testes in pediatrics. Curr Opin Pediatr. 2012;24:518-22.

136. Burton KA, McDermott DA, Wilkes D, Poulsen MN, Nolan MA, Goldstein M, Basson CT, McKnight GS. Haploinsufficiency at the protein kinase A RI alpha gene locus leads to fertility defects in male mice and men. Mol Endocrinol. 2006;20:2504-13.

137. Petersson F, Bulimbasic S, Sima R, Michal M, Hora M, Malagon HD, Matoska J, Hes O. Large cell calcifying Sertoli cell tumor: A clinicopathologic study of 1 malignant and 3 benign tumors using histomorphology, immunohistochemistry, ultrastructure, comparative genomic hybridization, and polymerase chain reaction analysis of the PRKAR1A gene. Hum Pathol. 2010;41:552-9.
138. Merke DP, Bornstein SR. Congenital adrenal hyperplasia. Lancet. 2005;365:2125-36

139. Speiser PW, White PC. Congenital adrenal hyperplasia. N Engl J Med. 2003;349:776-88

140. Murphy H, George C, de Kretser D, Judd S. Successful treatment with ICSI of infertility caused by azoospermia associated with adrenal rests in the testes: Case report. Hum Reprod. 2001;16:263-7.

141. Claahsen-van der Grinten HL, Otten BJ, Stikkelbroeck MM, Sweep FC, Hermus AR. Testicular adrenal rest tumours in congenital adrenal hyperplasia. Best Pract Res Clin Endocrinol Metab. 2009;23:209-20.

142. Bonaccorsi AC, Adler I, Figueiredo JG. Male infertility due to congenital adrenal hyperplasia: Testicular biopsy findings, hormonal evaluation, and therapeutic results in three patients. Fertil Steril. 1987;47:664-70.

143. Clark RV, Albertson BD, Munabi A, Cassorla F, Aguilera G, Warren DW, Sherins RJ, Loriaux DL. Steroidogenic enzyme activities, morphology, and receptor studies of a testicular adrenal rest in a patient with congenital adrenal hyperplasia. J Clin Endocrinol Metab. 1990;70:1408-13.

144. Rutgers JL, Young RH, Scully RE. The testicular "tumor" of the adrenogenital syndrome. A report of six cases and review of the literature on testicular masses in patients with adrenocortical disorders. Am J Surg Pathol. 1988;12:503-13.

145. Ashley RA, McGee SM, Isotaolo PA, Kramer SA, Cheville JC Clinical and pathological features associated with the testicular tumor of the adrenogenital syndrome. J Urol. 2007;177:546-9; discussion 9.

146. Wang Z, Yang S, Shi H, Du H, Xue L, Wang L, Dong Y, Han A. Histopathological and immunophenotypic features of testicular tumour of the adrenogenital syndrome. Histopathology. 2011;58:1013-8

147. Weksberg R, Shuman C, Beckwith JB. Beckwith-Wiedemann syndrome. Eur J Hum Genet. 2010;18:8-14.

148. Pettenati MJ, Haines JL, Higgins RR, Wappner RS, Palmer CG, Weaver DD. Wiedemann-Beckwith syndrome: Presentation of clinical and cytogenetic data on 22 new cases and review of the literature. Hum Genet. 1986;74:143-54.

149. Mangray S, deLellis RA. Pathology of the adrenal gland. In: Amin M, Grignon DJ, Srigley JR, Eble JN, editors. Urological Pathology. 1st ed. Philadelphia: Lippincott Williams \& Wilkins; 2014.205-60.

150. Cohen MM, Jr. Beckwith-Wiedemann syndrome: Historical, clinicopathological, and etiopathogenetic perspectives. Pediatr Dev Pathol. 2005;8:287-304.

151. Erickson LA, Rivera M, Zhang J. Adrenocortical carcinoma: Review and update. Adv Anat Pathol. 2014;21:151-9.

152. Cardinalli IA, de Oliveira-Filho AG, Mastellaro MJ, Ribeiro RC, Aguiar SS. A unique case of synchronous functional adrenocortical adenoma and myelolipoma within the ectopic adrenal cortex in a child with Beckwith-Wiedemann syndrome. Pathol Res Pract. 2012;208:189-94. 